\title{
The Teaching Of English In An Indonesian Islamic Boarding School: Design, Enactment, And Hindrances
}

\author{
Abdur Rohim \\ Student of Graduate Program in ELT, Universitas Islam Malang, Indonesia \\ Email corresponding author: abdurrohimofficial@gmail.com
}

\begin{abstract}
The present study described good practices, supporting learning factors, and language learning focus of students in English learning at Nurul Jadid by employing a qualitative research approach. The data were collected through observation, interview, and documentation from 60 students of an elementary, intermediate, and advanced level of 2019 academic year. The result shows that students of Nurul Jadid use English as their lingua franca to communicate with each other to make them comprehend the language directly. However to reach the goal of learning English effectively in Nurul Jadid, teachers select implicit and explicit learning activities in their extra-curricular programs such as; (1) speech, (2) discussion, (3) debate, (4) showing-opinion, (5) composing, (6) translation, (7) roomscompetition, (8) morning-talk, (9) native-day, (10) audio-visual, (11) quiz, and (12) evaluation-meeting. Besides, the study also shows that teachers of Nurul Jadid utilize some supporting learning factors to encourage the good practice of the learning process. They are curriculum used, the role of human resources, environmental setting, rules-obedient, and motivation effect. In addition, the finding also shows the language learning focus of the students of FLDI. The elementary student is the low-level that focuses on learning language structures, and the intermediate student is the medium-level that focuses on learning language application or language function. The advanced student is the high-level who learn about metalinguistic awareness or advance communication knowledge.
\end{abstract}

Keywords: English as a foreign language (EFL), English as lingua franca (ELF), explicit and implicit learning.

\section{INTRODUCTION}

There are four skills that need to be completed in learning a foreign language. The first is to listen; second is to speak, third is to read, and finally is to write. However, promoting students learning speaking skills earlier is also a good step to build fundamental progress in acquiring the language. It gives them the opportunity to use the language, make mistakes, and learn from them. Learning to speak is the most difficult part of the four skills. Students can learn reading, listening, and writing with a teacher or books, but in learning speaking, it requires immediate comprehension and real-time reaction. According to Craswell (2008:25) stated that speaking is one of the productive language skills that need the learning process. Added by Underhill (1987:96), speaking is a complex skill which needs the understanding and mastering the component of language proficiency such as, pronunciation, vocabulary, and grammar. Therefore the success of conducting speaking depends on the mastering of those components. If the components have been mastered well, the speaker will get success in speaking. But, if they do not master those components, the speaker will break the communication and difficult to transfer sustainable massages.

Teaching English to students of English as a foreign language (EFL) is always not easy. Teachers often missed in selecting an appropriate strategy to be implemented in the learning process. Rao (2000) suggested teachers conform their way of teaching through learners' ways from several points of view. Thus that teaching and learning styles would be matched accordingly. Somehow, the researcher found that students at the Foreign Language Development Institute (FLDI) of Nurul Jadid Islamic Boarding School were not difficult to learn English. It was proved by many of the new students who could use English as a daily language to communicate with each other easily. In another case, when English is used between speakers of other languages, it is called English as lingua franca (ELF). Jolivet (2017) believed ELF is not 
only a linguistic variety but also as a function or a reality of how English is used in the world. These terms are used as labels that reflect global English use.

By that basic reason, the researcher predicted that teachers of FLDI Nurul Jadid were using implicit and explicit learning strategy or conscious and unconscious process of learning to their students in order to be able to; encourage them learning English systematically, solve their learning problems naturally, and practice English speaking in the daily activity (24 hours) or using English as lingua franca (ELF) in all time. Ellis (1994) stated that implicit learning is typically defined as the acquisition of knowledge by a process that takes place naturally, simply, and without conscious operation.

In addition, Cleremans (1993) tries to straighten and simplify that implicit and explicit result from the representation of the structure that the environmental stimulus displays, and this knowledge is required from intentional and unintentional reflective strategies to learn. Therefore, the aim of an implicit or explicit focused on a form to attract learners' attention while minimizing any interruption to the communication of meaning" (Doughty and Williams, 1998).

Conventionally, teachers implement both implicit and explicit learning in EFL classrooms for better output. The implicit learning is meant to create an opportunity for learning without the students' awareness of what has been learned and help students to figure out from examples given to them" (Ellis, 1994, Griffiths, 2003). For example, finding new words of English through students' conversation then illustrating it in source language without knowing the writing is logically work out their own unconscious learning techniques and practical approaches. By contrast, in explicit learning, teachers apply conscious strategies to teach students through awareness in the process of learning (Richards, \& Schmidt, 2002). Explicit learning can involve language activities such as memorization techniques, hypothesis formation, or testing. To set focus on problem based on the background of the study, the research questions can be formulated as:

1. What are the good practices of English learning in Foreign Language Development Institute (FLDI) of Nurul Jadid Islamic Boarding School?

2. What are the good supporting factors of English learning in Foreign Language Development Institute (FLDI) of Nurul Jadid Islamic Boarding School?

3. What is the English language learning focus of students at Foreign Language

\section{METHOD}

This research was kind of case study (single case) and used descriptive-qualitative method to obtain the data needed. The researcher chose qualitative study in order to be able to give theoretical and practical contribution on language learning study. According to Moleong (2008:157) that the main data sources in qualitative research are words and the rest are additional data such as documents and others. The sources of the research data were consisting of primary and secondary data which were chosen and gathered in January 2019. Primary data were obtained directly from the results of interviews from sources or informants who ware considerable to provide relevant and actual information in the field. The writer used this data to obtain direct information about the data collection needed. The sources of the data were from both the teacher and students of Foreign Language Development Institute (FLDI) of Nurul Jadid Islamic Boarding School to avoid bias. The writer also collected additional data from some documents of FLDI Nurul Jadid such as the location of the institution, institution history, institution profile, lesson plan, report card-grades, institution vision and mission to strengthen the finding and complete information from teachers and staffs.

From 60 students of Foreign Language Development Institutes (FLDI) at Nurul Jadid Islamic Boarding School in Paiton - Probolinggo, 20 of the newest students of them were chosen to be 
main subject and the two upper levels were as additional to be observed in the research. They were all male students since male and female students were taught separately in Islamic Boarding School, who lived together 24 hours in a dormitory with several rooms. They were students of various senior-high school of Nurul Jadid Islamic Boarding School institution. There were 3 levels of students, elementary, intermediate and advance level which was classified based on learning-time length. Subjects were selected in case of required data needed such as low motivation to practice speaking, miss-used in pronunciation and difficulty to understand English vocabularies.

To obtain the data needed in this study the writer used triangulation technique in the process of collecting data, they were in the form of observation, interview and documentation which was conducted in February - March 2019. In this study, researcher used participant (for learner) and nonparticipant (teacher/tutor) observation because the researcher was involved as both researcher and observer who should act as flexible as fields' needed. The observation was conducted when the action or students' reaction was happening in all circumstances (conscious and unconscious). To keep the observation instrument effective and reach the goal of qualitative research, the researcher took careful notes and held in-depth observation such; OpenedQuestions attached to learners to be answered and field notes to write additional information. The researcher wrote every activities and programs supported for obtaining information in analyzing situations and learning environments of FLDI Nurul Jadid.

Interviews were conducted in-depth and structured to the subject of research with guidelines that have been made for respondents who were given the same questions. The researcher interviewed both sources (teachers and students) of FLDI Nurul Jadid to know the students' process of acquiring English language and problems appeared. In the observation and interview methods of qualitative research, the used of documentation studies are as a complement. In this study, researcher collected students' documentation data and prepared the necessary research equipment such stationary and recording devices.

After the data obtained through observation, interviews, and documentation, the next step was to do data analysis. Data analysis in this study was carried out qualitatively. The data analysis phase was carried out during April 2019. In line with research objective that was to describe what are the good practices, supporting factors, and language learning focus of students in English learning in Foreign Language Development Institute (FLDI) of Nurul Jadid Islamic Boarding School students in learning were analyzed.

Data analysis in qualitative research was carried out since before entering the field, while in the field and after completion in the field. In this study the data were analyzed through some steps, the activities included (a) Data collection; the researcher gathered the data collection results obtained from observation, interview, and documentation activities (b) Data reduction; the researcher chose the appropriate data needed based on the research questions of the study, (c) Data presentation, researcher described the selected data collection results with text or narrative, and the next step was (d) Draw conclusion, the researcher summarized the findings of the study to answers to research questions made. The conclusions were temporary and would be changed if there was no strong evidence found in the field. But if the conclusions were supported by valid and consistent evidence when the researcher returns to the field, the conclusions would be credible conclusions.

\section{RESULTS}


From the observations and interviews it was found that students of Foreign Language Development Institute at Nurul Jadid Islamic Boarding School could reach the goal of learning English, and there were some activities scheduled daily, weekly and monthly needed to be accomplished. The types and forms of extra-curricular activities are oriented to the development of discourse and life skill development, they are as follows:

\subsection{Speech Activity}

Speech program was conducted once a week. It helped students learn how to speak English fluently from using the right words, controlling volume/intonation and training the confidence when speaking in public. Students learned more since when preparing to make a speech to share inspiration through words to deliver all their ideas in front of audiences. To present clarity and efficiency ideas of speech students are required to apply both implicit and explicit learning skill in it. This program is a step to improve students' skills and evaluation of their abilities and development. The speaker must submit an article that must be corrected by counselor (FBI member) before the speaker submits it to the coordinator, the speech text in a maximum delivery of 7 minutes and at least 5 minutes. For students who cannot take part in the activity must show a permit letter. If the above rules are violated, the speaker must be punished by standing 30 minutes out of the class added by writing an article on standard folio paper.

Every student should join the activities carefully to be able to summarize the speaker's speech in minimum of 5 summary points for each. Summary must be written and submitted in a special book and presented the summary for 3 minutes at a minimum and a maximum of 5 minutes before the activity ended to the counselor. If one of the above rules is violated, the listener must be punished by standing 30 minutes out of the class while completing the assignment. Besides students were obligated to summarize the speakers' speech, they also need to take part in giving comment of speech activities from beginning to time. The comments must contain; a) Smoothness (pronunciation, intonation and speed of speech), b) Grammar and speech structure and c) Gesture of the speakers. The commentator must have objectively comment on all elements and become a wise judge who has an objective view. To control the agenda well, one of the students was selected to master the elements as the host. He managed the rundown, organize agenda of the speech, control listeners and master the articles.

\subsection{Discussion Activity}

Held three times a month, this activity was designed to increase students' knowledge in improving their language through sharing experience gained from Alumni of Foreign Language Development Institute who already have more experience in the field of education, business and or continuing their studies in the country or abroad such as United states of America, Australia, Japan and etc. and or discussing some currents issues. This activity was monopolized by educational staff of the Foreign Language Development Institute in improving the ability to speak in English and its use in the real world. This program is also one of the steps to improve students' skills and evaluation of their abilities and development. One student selected to master the elements as the host to manage the discussion based on the ethics of the discussion system. The duration of time is 15 minutes to convey the contents of the article that must be submitted 2 days before the discussion was held. Articles must be typed on paper ( 4 with the standard 12 times new font type romance with 1.5 spaces and margins (top, bottom, right, left) are 2, If the submitting an article was too late students would be punished to stand up and memorize 10 scientific vocabulary. Yet, for students who deny the task and or were oblivious the do the task will be punished (standing 1 hour) and presenting the discussion in the next discussion. If in the next discussion, the presenter still makes the same mistake, the punishment was added through 
memorizing 10 scientific vocabularies, face the board to be advised and make a discussion scheme. Every week there was only 1 presenter with two sessions focused; explanation of grammar and structure development as the first and second, commentary argument and content attack. All members must follow the activities carefully and actively with no any noise. Each room should delegate a representative in every level to ask and comment the whole discussion process. If one of the listeners violated the rules above, they would be punished to stand up during the activity.

\subsection{Debate Activity}

This activity was a kind of discussion some issues and debating between two teams on a specific subject or topic in an excellent way, which engages every member of the club learning and improving their fluency, vocabulary and confidence, held every week. By choosing popular debating topics and allowing the students to research they could learn new vocabulary to strengthen their case, and then they were able to express their own opinions without feeling embarrassed. All the students needed to be encouraged to participate in the debate and to be able to relate to the skill they are improving. This program was also one of the steps to improve students' skills and evaluation of their abilities and development. To deliver the team line and provide a clear definition, debater should master the debate system. The system used was APS (Asian Parliamentary system). Interruptions were allowed in the second minute until the sixth minute to be rejected or accepted by the speaker. There was no any interruption or denial of the speaker. To keep it effective, debaters were not recommended to attack personally, spend time as wise as possible (no less or even more), and face the listeners rather than debater when delivering arguments. Task of the MC was to organize activities from beginning to end or good element settings, keep agenda runs well, set the duration of time (time keeper), understanding the system, mastering the theme of the debate. Mastering the theme of the debate and the debate system was an obligatory for both debaters and listeners. Duration of presenting the motion of the debate was 7 minutes 20 seconds for the first to third speaker and 5 minutes for the repeat speaker. The debater was standing up when delivering argumentations. For debaters who were not present or absent in this program would be punished (standing 2 hours). The judge took part from beginning to end of the agenda and become a wise judge who has an objective view to value whole debate process and debate content on all elements and are they are chosen from intermediate and advance level (students). Students listened to the activities carefully to make a summary of both teams ( 3 points) positive and negative point of views. If it is violated, the listener must be punished to stand up about 30 minutes while completing the task.

\subsection{Showing-Opinion Activity}

This activity was to improve students' ability of speaking in English by discussing current issues which was held once a week. Besides, through this activity students were expected to be able to develop their critical thinking skills in seeing the perspective of the news that is required to always read the latest news. Therefore, reading skills were a very important part to be concentrated in this case since it was found that students have very large interest in reading the news (newspapers) provided by educational staff of the Foreign Language Development Institute. This program was also one of the steps to improve students 'skills through this type of activity students and managers could evaluate the ability and development of students' learning. MC in showing opinion activity was passionate as the host to organize all rundown agendas while giving simple explanation about background to the theme and take control of listener attention to avoid bias opinion focus. Besides it was suggested to listeners to master theme preserved specially and public interests generally to be their background knowledge or points to 
share before the activity started. If it is violated they must be punished by standing 30 minutes and complete the task. The duration of delivering argumentation was 5 minutes of each speaker which selected randomly.

\subsection{Composing Activity}

This program was to give students foundation in basic writing skills which was held twice in a month. Composition is a fundamental writing skill that takes several ideas and puts them in an order in a form of essay, report, presentation or a term paper, so readers can understand an idea or argument. Excelling in English Composition not only makes students be a good writer, but it also helps them develop great research, critical thinking and proofreading skills as well (Dumbauld, 2018). This program was also one of the steps to improve students' skills and evaluation of their abilities and development. Two levels of FLDI member (elementary and intermediate) were obligated to fulfill this task and an optional task for advance level students. The elementary students should submit articles of full-paper size and half-paper size for intermediate (folio paper). The essay must be in the coordinator hand at least an hour before the agenda time ended. The products were highly expected based on mechanism and systematic research writing result. The theme was announced before the event of the presence of maghrib time. Assessment criteria were evaluated from uniqueness, writing techniques, pooling ideas, and truth quotes. The most basic essays were assessed by capitalization, spelling mistakes, and vocabulary matches. The final assessment consisted: A (best), B (middle), C (enough), and D (worst).

\subsection{Translation Activity}

Translation is one of the best ways to learn a foreign language because the main idea is that if students who learn a foreign language they need to know their mother tongue very well. Translation is a good tool to adopt a metalinguistic attitude towards a language to understand how it really works. Translation is a necessary and useful part of language learning because it can also reveal important details about how two compared languages operate and check all linguistic skills. FLDI teachers used translation exercise for students' task as they believed it was an effective method of learning a foreign language. Additionally repeated practice of translating and retranslating between two languages helped students learning and thinking the overall message trying to convey. In this way they learn the grammar, syntax, lexicon and more in different ways. This agenda was Held every month in the second and fourth week in FLDI Nurul Jadid. Teachers provided articles to be translated for all members (based on the level) on the paper. The results of the translation must be collected to the coordinator in the first hour. To avoid the hassle and difficulty in translating, students should pay attention on the mechanism and systematic translation to gain more precise and suitable translation according to the context. If students did not complete the translation within 30 minutes before translation time ended, the punishments were waited for them. For correctors were from FLDI educators, Assessment criteria were related to accuracy and compatibility, The most basic translations were judged by capitalization, translation errors, and matching abilities, The final assessment consisted: A (best), B (medium), C (sufficient), D (worst).

\subsection{Rooms-Competition Program}

This program was conducted every week as an innovative step in an effort to improve the skills of students who perform well, to strengthen the cadres as a team of students, and to be trained in 
the implementation of various kind of competition and events at the Nurul Jadid, district and or provincial levels that could develop abilities in each field of language skills and increase the confidence of each student. The competitions held included speech, debate, translation, news anchor, wall magazine, poetry, drama, etc. Through this type of activity students and managers could evaluate the ability and development of student learning. Each room must delegate and display according to the specified schedule. This activity involved 5 competitions; News Reading, Poetry Parade, Storytelling, Speech, and Conversation. Members of rooms who did not comply would be punished as follows; 1 . All room members must stand up out of dormitory 1 hour, 2. The rooms that are most often defeated would be punished by cleaning the FLDI environment in a week, and 3. Those who participate in the competition are prohibited from participating in other competitions.

\subsection{Morning-Talk Program}

This program was designed to focus for elementary and intermediate students. The procedure was as the same as having tour-guide activity, they walk around Nurul Jadid Islamic Boarding School areas (about 5ha). The intermediate level acted as guide and attempted presenting and explaining whole things found surround to elementary one who acted as client with task to take note of each. By involving in this program students could obtain some benefits, like; reinforce self-confidence, hone presentation skill and enrich new English vocabulary. The basic purpose of the program was to refresh students' mind and to prepare them in facing the future real life challenge. In this activity, participants were asked to bring books, dictionaries and pens to help those taking notes about: demonstration of opinion, listening and conversations. For those who violated the rules of this activity would be sentenced to 30 minutes while completing their duties.

\subsection{Native-Day Program}

This program was set to be held 3 days every week (Saturday, Sunday and Monday). Imitate what native says, was the proper tagline described this agenda. In those times, students were obligated to speak as similar as native speaker says or pronounces by means it was prohibited to use incorrect English language style or accent (mother-tongue intervention). This practice continued to be used by students, even though they cannot perfectly pronounce the sound. There are various kinds of imitation namely spontaneous imitation, imitation of acquisition or elicited imitation, immediate imitation, delayed imitation and imitation with expansion. When the native day starts, those days were under the supervision of the FBI (Federasi Bahasa International). This policy was decided through the collective meeting result (annual meeting) toward the decreasing of the used of correct-English. All members and educators who were in the area of FLDI must speak English natively throughout the specified day to be habituated to the native speakers' accent without interfered by Maduranese, Javanese or even Indonesian accents. If they miss one of the above rules, they would be sentenced to stand 30 minutes and be given an academic sentence.

\subsection{Audio-Visual Activity (Watching Movie)}

Almost all students loved this activity which was only held once in a month as their favorite one. This agenda was kind of watching film or movie that brings lot more fun than studying with a textbook. In films, words are used as part of a story and this context helps students to learn and 
remember them more effectively. By watching British and American films, students could listen to native English actors speaking the language in a natural way in terms of vocabulary and style. Since Britain and America have different accents used to speak, students could hear many regional accents being used and it helped them understanding them easily. Textbooks seldom provided information about English accents. Another benefit of using film was that it provides a source of authentic and varied language. It provided students with examples of English used in 'real' situations outside the classroom, particularly interactive language - the language of reallife conversation, natural expressions and the natural flow of speech. If students are not living in an English-speaking environment, perhaps only film and television can provide learners with this real-life language input. Both elementary and intermediate levels were obligated and advance level was optional to join this activity carefully. After the agenda ended, they were asked to make synopsis of the film watched to keep them capturing the new knowledge.

\subsection{Quiz Program}

This weekly activity aimed to improve students' sense of competitiveness so they are able to motivate themselves to show their best abilities, to learn something new from their own friends in honing their skills, to build creativity in each field of language skills, and to increase the confidence of each student through starting mastery of vocabulary wealth, conversation/speaking, quality insight and creativity. Through conducting this activity, students and managers could evaluate their progress of teaching and learning and also determine strategy steps at the next stage of activity. Participants of this activity were all room members in FLDI of Nurul Jadid, they are Princeton University room, Harvard university room, Stanford university room and Oxford university room.

\subsection{Evaluation-Meeting}

This program purposed to equalize the perceptions of the management staff and teaching staff about the institution's programs and steps as evaluating teaching and learning activities, extracurricular and one-month institution management programs relating to teacher absenteeism, discipline, teaching and mentoring, achieving learning limits, teaching methods teachers, attendance list and work plans as well as potential and opportunities for institutional management development which was held once a month. The purpose of this evaluation meeting was to evaluate what FLDI members have done for their learning for a month, control process and alternate obstacles for future result. In brief, to be able to speak English well learners need to know automatically about communicative competence aspects such as grammatical competence, discourse competence, sociolinguistic competence and last one is strategic competence. However, the fastest method to improve English speaking fluency is through speaking the language a lot. But the easier way to acquire the English language based on the writer's perspective is by forcing learners to be a part of it.

For learners who want to acquire English language instantly should consider the idea to live or even only stay in abroad (English-speaking country), since they have to practice English speaking for a whole day along. They have not any other option to use other language except English, thus that condition would stimulate learners acquiring English language implicitly. However it needs much more funds instead of spending shorter time to master. For the second choice it is not need to be in a country whose first language is English to keep practicing. Everyone can actualize it in our or their own country by finding colleges or institutions nearby that offers (or obligates) learners using English language as daily language-speaking or using English as lingua franca (ELF). As an example; Foreign Language Development Institute (FLDI) of Nurul Jadid Islamic Boarding School utilized ELF as strategy to acquire the English speaking. 
Comprehensively, the researcher found that the implementation of explicit teaching through several activities above in Foreign Language Development Institute (FLDI) of Nurul Jadid Islamic Boarding School ware an appropriate steps to acquire and develop an English ability/skill. However, for long term-used of English the researcher believed to tunings of the explicit learning guided and governed by implicit learning that created better approaches or strategy in many newest kinds of innovative programs which also could be consolidated and reinforced by implicit and explicit knowledge itself. Thus, implicit learning and explicit learning are, as it were, two sides of a coin in language acquisition.

\section{CONCLUSION}

The summaries of the finding in teaching and learning process taken by the researcher are as follows; 1) The process of teaching \& learning English at the Foreign Language Development Institute (FLDI) of Nurul Jadid use implicit and explicit learning strategy. The strategy is applied through face-to-face activity as subject matter, direct practice in curricular activities, and extracurricular to enrich insight and practice material. The activities are in the form of speech, discussion, debate, showing-opinion, composing, translation, rooms-competition, morning-talk, audio-visual (watching movie), quiz, and evaluation-meeting. 2) The various activities of reaching and learning English at Foreign Language Development Institute (FLDI) of Nurul Jadid are supported with varied factors that are able to accommodate the development of the ability to speak, read, write, and hear in addition to develop the multiple intelligences that students have owned. The supporting factors are in the part of curriculum used, the role of human resources, environmental setting, rules-obedient and motivation effects, and 3) The basic principles of English language acquisition in Foreign Language Development Institute (FLDI) of Nurul Jadid concerned of building self-confidence, introducing English language with ease, building vocabulary and developing the learning process by creating interest in the language itself through natural process. However, teachers of FLDI also set the language focus of the students in each level to be reached, such as elementary students focus in leaning language structure, intermediate students focus in learning language function, and advanced students are focused to learn metalinguistic awareness or knowledge.

\section{REFERENCES}

Clark, Herbert H. (1977). Inferences in Comprehension. Stanford University. Retrieved from https://web.stanford.edu/ clark/1970s/Clark,\%20H.H.\%20_Inferences\%20in\%20com prehension \%201977.pdf

Cleremans, Axel. (1993). Mechanism of Implicit Learning: Connectionist Model of sequence processing. Cambridge: The MIT Press.

Doughty, C. \& Williams, J. (1998). Pedagogical choices in focus on form. InC.

Dumbauld, Beth. (2018). What is English Composition?. StrightLine Blog. Retrieved from https://www.straighterline.com/blog/what-is-composition-english/

Ellis, Rod. (1994). The Study of Second Language acquisition. Oxford: Oxford University Press.

Griffiths, C. (2003). Patterns of language learning strategy use.System, 31, 367-383. 
Jolivet, Elizabeth Rowley. (2017). English as a Lingua Franca in research articles: the SciELF corpus, la revue du Geras ASP. p. 145-158. Retrieved from https://journals.openedition.org/asp/4987

Kreshen, D. Stephen. (2009). Principles and Practicein in Second Language Acquisition. University of Southern California. Retrieved from http://www.sdkrashen.com/content/books/principles_and_practice.pdf

Mohali, T. \& Mohtar, T. (2019). Learner Strategies In Second Language Acquisition. University of Malaya. Retrieved from http://www.melta.org.my/index.php/11-melta-articles/161learner-strategies-in-second-language-acquisition

Moleong, Prof. Dr. Lexy J., M.A. (2008). Metodologi Penelitian Kualitatif. Bandung: PT Remaja Rosdakarya.

Nasution. (2003). Metode Research, Jakarta : PT. Bumi Aksara.

Rao, Z. (2000). Chinese students' perceptions of communicative and non-communicative activities in the EFL classroom.System, 30, 85-105.

Richards, J. C.,\& Schmidt, R. (2002). Longman dictionary of language teaching \& applied linguistics (3rd ed.). Boston, MA: Pearson Education, Ltd.

Sundari, Weli. (2018). PEMEROLEHAN BAHASA. Jurnal Warna V o l. 2 , N o. 1, Juni 2018. Retrived from http://ejournal.iaiig.ac.id/index.php/warna/article/view/43

Underhill, N., (1987). Testing Spoken Language: A Handbook of Oral Testing Techniques, New York: Cambridge University Press. 